\title{
Expériences réalisées \\ sur l'écoulement de l'eau dans un tube, à des vitesses de tourbillonnement élevées
}

\section{Experiments on the flow of water in a tube at high rates of swirl}

PAR A.M. BINNIE ET M.Y.M. KAMEL

ENGINEERING LABORATORY, CAMBRIDGE

\begin{abstract}
Le monvement à l'intérienr d'une chambre de toubillonnement a wue et ì dear extremités a fit sinule en faisant touner la partie centrale d'un long tube horizontal en plexiglas et en admettant de l'eal sous l'effet de la pesantear par de nombreux trous dans cette zone. On a pu, de celte facon, mesurer la bitesse de lourbillonnement à l'entrée, et la faire varier sans changer le débit. Par aillears, en placant diverses obstructions dans les parties fixes du tabe, on a pu examiner la forme de l'́conlement en injectant de la conleur. On a retrouvé le « contre-icoulement $»$ arial constaté dans des expériences antériellres faites sur des buses de gros calibre. Aux roinies tourbillonnaires plus intenses, il s'est ćtabli un régime dans lequel trois couranls se dirigeaient vers lorifice de l'obstruction; un le long de l'axe, un autre près de la paroi, et un iroisibme le long d'un axe situé a environ un demi-rayon de l'axe médian; il I avait également deux conrants intermédiaires qui s'éconlaient dans le sens opposé. Les résultats numériques sont présentés souts forme adimensionnelle.
\end{abstract}

\begin{abstract}
The motion inside a single-and a double-ended swirl chamber was simnlated by rotating the central part of a long horizontal perspex tabe and admitting water under gravity through numerous holes in this portion. Thus the suriting velocity at entrance could be measur.. ed, and it could be changed without altering the discharge. With varions obstructions in the fixed parts of the tabe, the flow pattern was cxamined by means of injected colour. The reversed axial flow, which had been discovered in previous experiments on large nozzles, was again found. At higher suirls a regime occurred, which consisted of three streams moving towards the orifice of the obstruction along the aris, close to the wall, and at about half radins, with two intermediate streams in the opposite direction. Numerical results are presented in dimensionless form.
\end{abstract}

\section{I. - INTRODUCTION}

Le travail expérimental fait sur l'écoulement d'eau en régime tourbillonnaire dans une buse convergente (Binnie \& Teare, 1956) et dans une buse convergente-divergente (Binnie, Hookings \& Kamel, 1957) a montré que le mouvement est loin d'être tel que le prédit la théorie. Dans cette théorie (Binnie \& Harris, 1950), il a été supposé que le liquide était non visqueux, de sorte que le tourbillon (c'est-à-dire la composante tangen-
Experimental work on the flow of swirling water through a convergent nozzle (Binnie and Teare, 1956) and through a convergent-divergent nozzle (Binnie, Hookings \& Kamel, 1957) has shown the motion to be very different from that predicted by theory. In this theory (Binnie \& Harris, 1950) the liquid is assumed to be inviscid, hence the swirl (or tangential component of velocity) is inversely proportional to 
lielle de la vitesse) était inversement proporLionnel au rayon, le centre de la section étant occupé par un « noyau »d'air. En outre, la théorie supposait que l'angle d'inclinaison de la paroi de la buse par rapport à l'axe était si faible que lon pouvait négliger la composante radiale de la vitesse. Avee ces hypothèses, l'analyse devenait un des nombreux problèmes " d'écoulement critique », dont le premier à être résolu était celui de l'écoulement d'un fluide compressible et non visqueux par un convergent-divergent (Reynolds, 1886). Il paraîtrait, d'après cette simple théorie, que :

- Si le tourbillon est suffisamment intense, le débit devrait cesser, puisque, à l'ćtranglement, toute la charge disponible est absorbée pour conférer un supplément d'effet tourbilIon au fluide, de sorte qu'il n'en reste plus pour fournir une vitesse axiale.

- La vitesse axiale est miforme sur chaque section.

La première de ces hypothèses n'est pas confirmée par les observations pratiques courantes, même lorsque la viscosité est faible, telle the radius, and the central part of the crosssection is occupied by an air core. It is further supposed that the nozzle wall is inclined to the axis at so small an angle that the radial component of velocity may be neglected. With these assumptions the analysis becomes another of the so-called "critical-flow" problems, the first of which to be solved was the flow of a compressible inviscid fluid through a convergent-divergent nozzle (Reynolds, 1886).

From this simple theory it appears (i) that, if the swirl is sufficiently great, the discharge should cease because at the throat all the available head is absorbed in imparting additional swirl to the liquid and none remains to provide axial velocity; (ii) that the axial velocity over each cross-section is uniform. Common observation does not support the former prediction even when the viscosity of the liquid is low, as is the case with water. The experiments menlioned above were conducted on nozzles with semi-angles not exceeding $10^{\circ}$, and on a fairly large scale so that the boundary layers on the walls were proportionately very thin. Nevertheless, they failed in a striking manner to confirm the latter prediction, for when permanga-

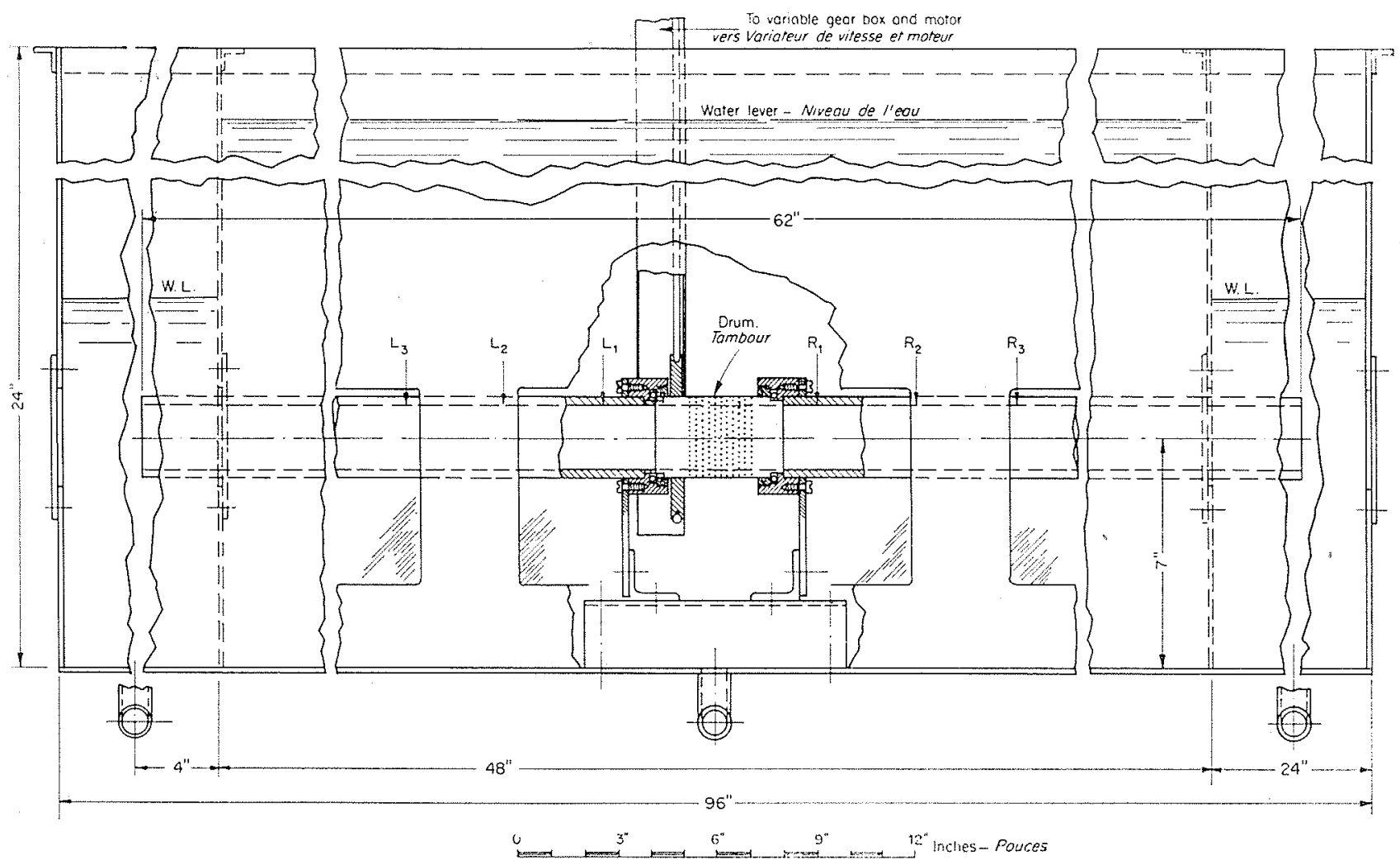

FIg. 1

Vue de côté de l'installation, avec coupe partielle.

Side elevation of apparatus. 
celle de l'eau. Les expériences citées plus haut ont été effectuées sur des buses dont les demiangles ne dépassaient guère $10^{\circ}$; de plus, on a utilisé une échelle assez grande, de sorte que les couches limites aux parois étaient proportionnellement très peu épaisses. Toutefois, les observations faites ont très nettement manqué de confirmer la deuxième des hypothèses précitées, car lorsque nous avons injecté une solution de permanganate à environ mi-rayon et en des points relativement éloignées des buses en plexiglas, nous avons pu constater que la couleur se déplaçait quelquefois dans le sens opposé à celui du courant principal, disparaissant assez rapidement dans le réservoir alimentant la buse.

Il est difficile de mesurer la répartition des vitesses à l'entrée d'une buse alimentée d'un réservoir classique, et il n'a pas été possible de déterminer quantitativement les conditions produisant ledit « contre-écoulement». On a par la suite construit un appareillage spécial (Binnie, 1957) analogue à celui dè la figure 1, afin d'étudier ce phénomène de plus près. Dans cette installation, on faisait tourner la partie centrale d'un long tube en plexiglas, admettant de l'eau sous l'effet de gravité par de nombreux trous dans le «tambour » rotatif ainsi constitué. Le lourbillon à l'entrée du tube était donc défini et facilement mesurable, et on a examiné la nature de l'écoulement dans les parties fixes du tube au moyen d'injections de couleur. Quatre installations ont été essayées, toutes avec les sorties du tube submergées :

A) Ecoulement symétrique sans obstructions dans les parties fixes;

B) Ecoulement asymétrique, produit en obturant la sortie de la partie de gauche du tube;

C) Ecoulement symétrique, en plaçant un bouchon à orifice central (diaphragme) dans chacune des parties fixes, simulant de la sorte un genre de chambre tourbillonnaire à deux extrémités;

D) Ecoulement asymétrique, avec la partie de gauche obturée près du tambour, et avec un diaphragme à orifice central dans la partie de droite, simulant un genre de chambre tourbillonnaire à extrémité unique.

On a pu observer trois régimes différents dans les tubes fixes, au voisinage du cylindre:

I. - Ecoulement vers l'aval sur toute la section;

II. - Ecoulement vers l'amont près de l'axe, et vers l'aval près de la paroi;

III. - Ecoulement vers l'aval près de l'axe et des parois, et vers l'amont, à des rayons intermédiaires. nate solution was injected at about half radius at points not close to the throats of the Perspex nozzles, the colour sometimes moved in the opposite direction to that of the main stream and quickly disappeared into the leservoir from which the nozzle drew its supply.

The velocity distribution at the entrance to a nozzle attached to a conventional reservoir is difficult to measure, and the conditions that produced this reverse flow, as it is termed, could not be determined quantitatively. To investigate the matter further, apparatus was constructed (Binnie, 1957), closely resembling that shown in Figure 1. The central part of a long Perspex tube was caused to rotate, and water was admitted under gravity through numerous holes in this revolving drum. Thus the swirl at entry to the tube was definite and easily measured, and the nature of the flow pattern in the fixed parts of the tube was examined by means of colour injections. With the tube outlets submerged, four arrangements were tested:

A) Symmetrical flow with no obstructions in the fixed parts.

B) Asymmetrical flow produced by blocking the outlet of the left-hand part.

C) Symmetrical flow with a bung containing a central hole in both the fixed parts, simulating a kind of double-ended swirl chamber.

D) Asymmetrical flow with the left-hand part blocked close to the drum and with a bung containing a central hole in the right-hand part, simulating a kind of single-ended swirl chamber.

Three alternative regimes were observed in the fixed tubes near the drum :

I.-Downstream flow over the whole crosssection.

II.-Upstream flow near the axis and downstream near the wall.

III.-Downstream flow near the axis and near the walls, and upstream at intermediate radii. Two sub-divisions of this type may be distinguished, which will be designated III when the downstream flow near the axis was feeble and did not extend far down the fixed tube, and III' when this stream was vigorous and persisted through an obstruction. The latter type, even if lacking an air-core, resembles the reverse flow seen in the nozzles. 
Ce régime présente deux variantes, que nous désignerons par III pour le cas où l'écoulement vers l'aval près de l'axe est faible et ne s'étend pas sur une grande longueur du tube, et par III' pour le cas où ce courant est intense, persistant même à travers une obstruction. Ce deuxième type, bien qu'il ne comporte aucun noyau d'air, ressemble au contre-écoulement que l'on a constaté dans les buses.

Les résultats ont été présentés en fonction de deux paramètres définis par:

$$
\mathrm{R}=a u v / \mathrm{v} \text { et } \mathrm{V}=a v / \mathrm{v}
$$

a étant le rayon du tuyau, v la viscosité cinématique, "b la vitesse axiale moyenne de l'eau dans le tube, et $v$ la composante de vitesse tangentielle qui lui est imposée à l'entrée. Des schémas de régime ont été tracés pour chacune des dispositions, avec $\mathbf{R}$ pour abscisse et $\mathbf{V}$ pour ordonnée. La vitesse maximum du cylindre a été limitée à $40 \mathrm{tr} / \mathrm{mn}$ pour des raisons mécaniques, et l'appareil était uniquement conçu pour fonetionner en régime laminaire, où le problème peut ètre résolu théoriquement, sous certaines restrictions, au moyen de méthodes de relaxation employant les équations complètes du mouvement visqueux (Vaisey, 1956). Toutefois, on a observé dés tourbillons atteignant $5000 \mathrm{tr} / \mathrm{mm}$ dans les buses, près du « noyau » d'air (Binnie et autres, 1957), de sorte qu'il a été nécessaire de construire un nouvel appareil dont le cylindre tournait à une vitesse maximum de 850 $\mathrm{tr} / \mathrm{mm}$, afin de pouvoir étendre les observations dans le tube à des vitesses tourbillonnaires de cet ordre. L'objet du présent article est de décrire les expériences effectuées sur cette nouvelle installation.
The results were presented in terms of two parameters defined by :

$$
\mathbf{R}=a w / \nu \text { and } \mathrm{V}=a v / \%,
$$

where $a$ is the pipe radius, viscosity, $w$ is the mean axial velocity of the water in the tube, and $v$ is the swirl velocity imposed on it at entry. For each arrangement, regime diagrams were drawn with $R$ and $V$ as axes. For mechanical reasons the maximum speed of the drum was 40 r.p.m., and the apparatus was designed to operate only under laminar conditions, where the problem is soluble theoretically, under certain restrictions, by means of relaxation methods employing the complete equations of viscous motion (Vaisey, 1956). In the nozzles, however, swirls as high as 5,000r.p.m. were found near the air-core (Binnie et al., 1957), therefore to extend the observations in the tube to swirls of this order of magnitude, fresh equipment was built to permit a maximum drum speed of 850 r.p.m. The purpose of this paper is to describe experiments made with the new apparatus.

\section{II. - DESCRIPTION DE L'INSTALLATION D'ESSAI II.-DESCRIPTION OF APPARATUS}

Un tube en plexiglas d'une longueur de 62 pouces, d'un diamètre extérieur de 2 pouces et dont l'épaisseur de paroi était de $1 / 4$ de pouce, était monté symétriquement dans un bassin ouvert en tôle tel que représenté sur la figure 1. Le bassin, qui mesurait 1 pied de large et 2 pieds de profondeur, était éruipé de deux cloisons verticales formant un compartiment médian d'une longueur de 4 pieds, et deux compartiments terminaux d'une longueur de 2 pieds reliés entre eux par voie extérieure. Les deux còtés du compartiment médian comportaient des panneaux transparents pour fa-
A Perspex tube, 62 in. long, 2 in. in internal diameter and with a wall $1 / 4 \mathrm{in}$. thick, was fixed symmetrically in an open steel tank, as shown in Figure 1. The tank, which was $1 \mathrm{ft}$ wide and $2 \mathrm{ft}$ deep, was divided by two vertical diaphragms into a central compartment, $4 \mathrm{ft}$ long, and two end compartments, 2 it long and connected exnernally. Windows were fitted in both sides of the central compartment to facilitate visual and photographic observations, and external gauge glasses indicated the levels in the compartments. The central $41 / 4$ in. of the tube formed the revolving drum; it was supported on ball bear- 
ciliter des observations visuelles et photographiques; des tubes de niveau extérieurs indiquaient les niveaux dans les compartiments. La partie centrale, de $41 / 4$ pouces, du tube conslituait le tambour tournant, qui, lui, était monté sur des roulements à billes et comportait $\mathbf{6 6 0}$ trous de 0,08 pouce de diamètre, percés sur 11 rangées en quinconce, l'intervalle entre chaque rangée étant de $3 / 16$ de pouce. Le tambour ćtait muni de joints annulaires d'étanchéité à chacune de ses extrémités et était entrainé par une courroie passant à l'extérieur du bassin autour d'uue poulie entraînée par un moteur élecIrique et un varialeur de vitesses (ce dernier n'est pas représenté sur la figure). La courroie était protégée par un carter qui, bien qu'il ne soit pas entièrement étanche, empèchait toute perturbation de l'eau dans le compartiment central. Deux cuves à niveau constant étaient prévues, dont chacune comportait un long seuil déversant. La première de, ces cuves était reliée aux compartiments terminaux et $\mathrm{y}$ maintenait un niveau constant; le débit fourni était déterminé au moyen d'un tube de verre sradué. L'autre cuve était sensiblement surélevée par rapport au bassin principal et alimentait le compartiment central par l'intermédiaire d'un Luyau comportant un robinet de réglage. Etant donné que ce tuyau se terminail au-dessus de la surface libre (où la perturbation était éliminée grâce à des chicanes), le débit traversant l'installation était indépendant de la vitesse de rotation du tambour, et toute variation de cette vitesse modifiait le niveau du compartiment central. Les injections de solution de permanganate se faisaient au moyen d'une sorte d'aiguille hypodermique, par les points $R_{1}, R_{2}$ et $R_{3}$ du côté droit de l'appareil situés à 1,4 et 7 pouces de son entrée, ainsi que par les points $L_{1}, L_{0}$ et $L_{3}$ dans la partie gauche et à des distances correspondantes de $1,45,4,45$ et 7,45 pouces. ings, and in it 660 holes of diameter $0.08 \mathrm{in}$. were drilled in 11 staggered rows $3 / 16$ in. apart. The drum was fitted with sealing rings at each end, and it was rotated by a belt that passed up out of the lank to a pulley driven by an electric motor through an infinitely-variable gear-box (not shown). The belt was enclosed in a case which, though not completely watertight, ensured that the belt did not disturb the water in the central compartment. Two constant-level tanks were provided, both with long over-flow weirs. One, connected to the end compartments, maintained a steady level in them, and the discharge from it was measured with a graduated glass cylinder. The other, which was fixed well above the main tank, supplied the central compartment through a pipe fitted which a regulating valve. As this pipe terminated above the free surface (where the disturbance was removed by baffles), the discharge through the apparatus was independent of the rotational speed of the drum, changes in which caused alterations in the level in the central compartment. The water was circulated through the system by a pump. Permanganate solution could be inserted by a hypodermic tube through the tappings $R_{1}, R_{2}, R_{3}$ in the right-hand part at distances $1,4,7 \mathrm{in}$. from its inlet and through tappings $L_{1}, L_{3}, L_{3}$ in the left-hand part at corresponding distances 1.45 , $4.45,7.45$ in.

\section{III. -- RESULTATS DES ESSAIS. SCHEMA DE REGIME III.-EXPERIMENTAL RESULTS.-REGIME DIAGRAMS}

Ayant submergé les sorties afin d'empêcher à l'air d'entrer et de constituer un « noyau », nous avons établi les schémas de régime des figures 2 à 7 pour la section transversale $R_{1}$, sur la base des observations faites au moyen d'injections de couleur. Le procédé habituel était de régler le débit à une valeur fixe et de faire varier la vitesse du tambour par paliers; les résultats obtenus étaient les nêmes, que la vitesse augmente ou
With the outlets submerged so that air could not enter and form a core, the regime diagrams shown in Figures 2-7 were constructed for the cross-section $R_{1}$ from observations of injected colour. The usual procedure was to set the discharge at a fixed value and to alter the drum speed in steps; the results were the same whether the speed was rising or falling. When these experiments had been concluded, those 
diminue. Apris ces essais, nous avons repris ceux laits avec les installations $C$ et $D$, mais cette lois avec les sorties situées au-dessus du niveau des compartiments terminaux. Dans cerluines conditions, nous avons pu observer un - noyau », tel que nous le décrirons dans le paragraphe IV, mais par contre, nous n'arons constaté aucune modification des schémas de régime.

Ainsi que nous nous y attendions, nous avons loujours constaté le régime I lorsqu'il n'y avait pas de tourbillonnement. Dans l'autre condilion exirème, $R=0$, le régime II s'établissait près du point $R_{1}$ lorsque le tourbillon était relativement faible. Dans les cas où il y avait un bouchon plein dans le voisinage, l'eau avoisinante tourbillonnait beaucoup moins et se trouvait dirigée ver's l'axe, de la facon expliquée en premier lieu par J. Thomson en 1857. Il pouvait, de cette facon, se produire un courant de circulation s'écoulant vers l'akal près de la paroi et vers l'amont près de l'axe. Ce phénomène se produisait même dans lé cas où le bouchon était très éloigné, ou même absent, car la paroi et la masse d'eau morte produisaient aussi un effet analogue. A un régime plus tourbillomnaire, nous avons pu observer le régime faible III, la limite variant en fonclion' de l'installation utilisée. Le courant retolirnait au tambour ne s'écoulant plus le long de l'axe, tel que précédemment, mais entre celui-ci et la paroi, et on pouvait également constater qu'une partie de la couleur injectée se décantait temporairement sous la forme d'un còne creux stagnant dont la base reposait sur la section transversale médiane, et le sommet en un point qui se déplacait vers l'aval à mesure que $V$ augmentait. Près de la paroi intérieure du còne, l'écoulement se dirigeait lentement vers l'amont, cette eau retournant ensuite ver's l'aval près de l'axe. Ainsi, nous avions d'une part le régime III en $R_{1}$, et, d'autre part, le régime II aux sections plus éloignées; toutefois, lorsque $R=0$, le mouvement n'était pas permanent et le sommet du cône se déplacait alternativement d'un cóté à l'autre de la section $R_{1}$, de sorte qu'il a cté nécessaire de désigner ces observations par un symbole combiné.

Les résultats obtenus lorsque $\mathbf{R}$ et $\mathbf{V}$ étaient tous les deux plus grands que zéro dépendaient largement de la disposition essayée, et nous donnerons des précisions séparées pour chaque cas; toutefois, pour $A$ et $B$, étant donné leur intérêt moindre, nous n'en donnerons qu'une brève description. Dans tous les essais, le courant principal en $R_{1}$ était, pour la plus grande partie, concentré dans une zone annulaire près de la paroi. On n'a pu observer un régime d'écoulement laminaire qu'aux faibles vitesses. Etant donné les conditions défavorables se produisant à l'entrée with arrangements $C$ and $D$ were repeated with the oullets above the level in the end compartments. Under certain conaitions a core then appeared in the manner that will be described in $\$ I V$, but no alterations in the regime diagrams were detected.

At zero swirl regime I was, of course, always seen. At the other extreme, $\mathrm{R}=0$, regime II occurred near the tapping $R_{1}$ when the swirl was relatively small. If there was a solid bung nearby, the neighbouring water lost much of its swirl and was forced towards the axis in the manner first explained by J. Thomson (1857). Thus a circulation could be set up with downstream flow near the wall and upstream near the axis. This effect occurred even if the bung was far distant or absent, for the wall and the mass of dead water also exerted a similar drag. At greater swirls, the limit varying with the arrangement in use, the feeble regime III was seen. The stream returned into the drum, not along the axis as before, but at an intermediate radius, and some of the injected colour settled for a time into the form of a stagnant hollow cone with its base on the central cross-section and its apex at a point that moved further downstream as $V$ was increased. Near the inner wall of the cone the flow was slowly upstream, and this water returned downstream near the axis. Thus the regime was III at $R_{1}$ and II at more distant crosssections; at $\mathrm{R}=0$, however, the motion was not steady and the apex moved to and fro across the section $R_{1}$, therefore these observations are denoted by a combined symbol.

The results with both $\mathrm{R}$ and $\mathrm{V}$ exceeding zero depended greatly on the arrangement under test, and a separate account of each will be given; but $A$ and $B$, being of less interest, need only a brief description. In all the experiments the main stream at $R_{1}$ was largely concentrated in a narrow annular zone near the wall. Laminar flow existed only at low velocities. Owing to the poor entry conditions, with arrangement A and zero swirl turbulent flow was seen at $R_{1}$ when $R$ was as low as 400 ; this limit fell when swirl was introduced, being 200,70 and 0 at $\mathrm{V}=350,1,000$ and 3,500 , but under these conditions the axial velocity was far from uniform over the section. The same trend was noticed by Talbot (1954), who infused swirl into a stream passing through a long tube by rotating part of the tube.

\section{(i) Arrangement A. - Symetrical flow with NO OBSTRUCTIONS IN THE FIXED TUBES.}

Throughout these tests the flow remained symmetrical about the central cross-section. Whereas in the slow-speed experiments the entire diagram was occupied by regime II except 
sur l'installation A lorsqu'il n'y avait pas de tourbillon, un ecoulement turbulent apparaissait en $R_{1}$, même lorsque $\mathbf{R}$ n'était que de 400 ; cette. limite diminuait lorsqu'on introduisait un tourbillon et se situait à 200,70 et 0 pour $\mathrm{V}=350$, 1000 et 3500 . Toutefois, dans ces conditions, la répartition des vitesses axiales était loin d'être uniforme à travers la section. La même tendance a été observée par 'Talbot (1954), qui introduisait un tourbillon dans un courant passant par un long tube en en faisant tourner une partie.

a) Installation A. - Ecoulement symétrigue SANS OBSTRUCTIONS DANS LES IUBES YIXES.

Dans tous ces essais, l'écoulement est resté symétrique autour de la section transversale médiane. Tandis que, dans les essais à vitesse réduite, le régime II occupait la totalité du schéma, sauf dans le voisinage de l'axe de $R$, cette fois, le régime III est apparu sous la forme précisée plus haut, dans toute la zone $100<\mathrm{R}<1000$, $1200,<\mathrm{V}<60000$ approximativement.

\section{b) Installation B. - Ecoulement asymétri-} QUE : SORTIE DU TUBE DE GAUCHE OBTURÉE.

Dans, ces conditions, le régime II ne se produisait qu'au voisinage de de l'axe $\mathbf{V}$ et, aux valeurs plus élevées de $\mathrm{R}$, le mouvement se transformait directement de I en III à mesure que $\mathrm{V}$ augmentait. Ce phénomène était dù à la circulation dans le tube de gauche. Aux faibles vitesses de rotation, c'est-à-dire $50 \mathrm{tr} / \mathrm{mm}$, il était possible de suivre une injection de couleur faite au voisinage immédiat de l'extérieur du tambour, et on a pu constater que presque la moitié du volume d'eau entrant dans le tambour pénétrait en premier lieu dans le tube de gauche près de la paroi. Des injections faites en $L_{1}$, lorsque le tourbillon était plus important, ont confirmé que ce courant retournait au tambour plus près du centre (en des rayons plus petits), s'opposant ainsi à la tendance du régime II à s'établir en $\mathrm{R}_{1}$, et passait à l'extérieur du cône stagnant du régime III. Ce faisant, le courant s'opposait au courant de retour qui, lui, était encore plus faible que dans l'installation $A$, et le sommet du cône pouvait se trouver parfois repoussé au-delà de $\mathbf{R}_{3}$.

\section{c) Installation C. - Ecoulement symétrioue: OBSTRUCTIONS DANS LES TUBES FIXES.}

Dans ces conditions, l'écoulement se trouvait freiné symétriquement par deux paires de diaphragmes, de forme différente, montés alternativement, soit (a) des disques en laiton percés d'un trou central de 0,25 pouce de diamètre, soit, (b) des buses convergentes de forme conique en plexiglas dont le demi-angle était de $15^{\circ}$ et le near the axis of $R$, regime III now appeared, in the manner described above, in the whole of the region $100<\mathrm{R}<1,000,12,000<\mathrm{V}<60,000$ approximately.

(ii) Arrangementr B.-Asymmetrical flow With THE OUTLED OF THE LEFT-HAND TUBE: BLOCKED.

Here regime II occurred only near the axis of $\mathrm{V}$, and at higher values of $\mathrm{R}$ the motion changed direct from I to III as V was increased. This effect was caused by the circulation in the lefthand tube. At low rotational speeds, e.g. 50 r.p.m., colour inserted just outside the drum could be followed, and nearly half the water entering the drum was seen to go first into the left-hand tube close to the wall. Injections at $\mathrm{L}_{1}$ at higher swirls confirmed that this stream returned to the drum at smaller radii, thus resisting the tendency for regime II to form at $R_{1}$, and passed outside the stagnant cone of regime III. In so doing, it opposed the reverse flow, which was even feebler than in arrangement $A$, and the apex of the cone was sometimes pushed beyond $R_{3}$.

(iii) Arrangement C.-Symmetrical rlow with OBSTRUCTIONS IN THE FIXED TUBES.

The flow was now symmetrically impeded by two alternative pairs of bungs, (a) brass disks with a central hole 0.25 in. in diameter, (b) Perspex convergent nozzles of conical shape having a semi-angle $15^{\circ}$ and a throat diameter $0.29 \mathrm{in}$. Regime diagrams are shown in Figures 2 and 3 , the bungs being in the position $z / a=8$, where $z$ is the distance of the orifice from the inlet of the fixed tube and $a$ is the tube radius. The upper right-hand part of the diagram was unattainable, as the height of the tank above the drum was not great enough to provide all the extra head required by the obstructions. In Figure 2, where the range of the earlier work is indicated in the bottom left-hand corner, it will be seen that the vigorous regime III' now appeared. With $\mathbf{R}$ exceeding a very low limit, the change from I to III', as the speed was increased, was indicated by a fall and eventually a reversal of the axial velocity at about half radius. A pattern was then set up in which the upstream flow at $R_{1}$ divided inside the drum; one portion was caught up into the stream near the wall, and the other, revolving strongly, returned near the axis and went out through the central part of the hole. The origin of this pattern seemed to be a squeezing action between the axial stream just mentioned and the inward flow over the face on the bung, which formed the other source of the discharge through the hole. With arrange- 
diamètre à l'étranglement de 0,29 pouce. Les schémas de régime sont donnés dans les figures 2 et 3 ; les diaphragmes etaient en position $z / a=8$, $z$ étant la distance du diaphragme à l'entrée du tube fixe et $a$ le rayon du tube. Nous n'avons pu obtenir des résultats pour la partie supérieure de droite du schéma, puisque la surélévation du bassin par rapport au tambour n'était pas suffisante pour pouvoir fournir toute la charge supplémen. taire nécessaire pour vaincre les obstructions. Dans la figure 2, où l'étendue des essais précédents est indiquée dans le coin en bas à gauche, on a pu constater l'apparition du vigoureux régime III'. Lorsque $\mathrm{R}$ dépassait une certaine limite très basse, le passage de I à III', à mesure que la vitesse augmentait, se manifestait par, d'abord, une diminution, et, finalement, par un renversement de la vitesse axiale en un point situé approximativement à mi-rayon. Le spectre de l'écoulement était alors tel que le courant amont en $R_{1}$ se divisait à l'intérieur du tambour; une partie se trouvait entraînée par le courant près de la paroi, tandis que l'autre, en régime de rotation très prononcé, retournait près de l'axe et sortait par la partie centrale du diaphragme. Cette répartition semblait être due à un phénomène de « resserrement » entre le courant axial précité et l'écoulement ver's l'intérieur sur la surface $d u$ bouchon, qui constituait la deuxième source du débit à travers le diaphragme. Dans les installations $A$ et $B$, nous avions constaté que la présence d'un tube d'injection de couleur d'un diamètre extérieur de 0,043 pouce ne perturbait aucunement l'écoulement; toutefois, en présence des vitesses considérables s'étendant jusqu'à l'axe, il était maintenant nécessaire de réduire les dimensions du tube autant que pratiquement possible (diamètre extérieur 0,028 pouce). Lorsqu'il était possible de le faire, nous avons toujours retiré ce tube très rapidement, et dans certains cas, nous avons cherché à assurer la symétrie en passant un «faux-tube » par le point correspondant situé sur l'autre côté du tambour.

Lorsque nous avons remplacé les disques par les buses (fig. 3), il s'est établi le régime dit $V$. dans lequel existaient des courants vers l'aval près de l'axe, près de la paroi, et entre les deux; des courants vers l'amont se produisant dans les deux zones intermédiaires ainsi formées. Nous avons pu obtenir le même phénomène avec les disques, en les montant plus près l'un de l'autre, de telle sorte que le tourbillon, dans leur voisinage, soit augmenté. La plus grande partie d'un filet de couleur injecté à la périphérie du disque se partageait au voisinage de l'axe, une partie passant par le diaphragme alors que l'autre se dirigeatt vers l'amont. Ce courant de retour était alors refoulé par le courant central qui l'entraînait avant de se séparer lui même en deux portions, dont l'une, la portion intérieure, ments $A$ and $B$ a colour-injection tube of outside diameter $0.043 \mathrm{in}$. was found not to disturb the flow, but the high velocities extending to the axis now required the smallest practicable tube

\begin{tabular}{|c|c|c|}
\hline \multicolumn{2}{|c|}{ Notation des fig. 2 à 7 : } & Notation for figures $2-7$ : \\
\hline 0 & Régime I & Regime I \\
\hline & Régime II & fegime $I I$ \\
\hline 人 & Régime III & Regime $I I I$ \\
\hline+ & Régime II' & Regime III' \\
\hline 0 & Régime $\mathrm{V}$ & Regime $V$ \\
\hline ) & "Noyou" dans l'orifice seulement & Core in orifice only \\
\hline & Noyau complet & Complete core \\
\hline
\end{tabular}

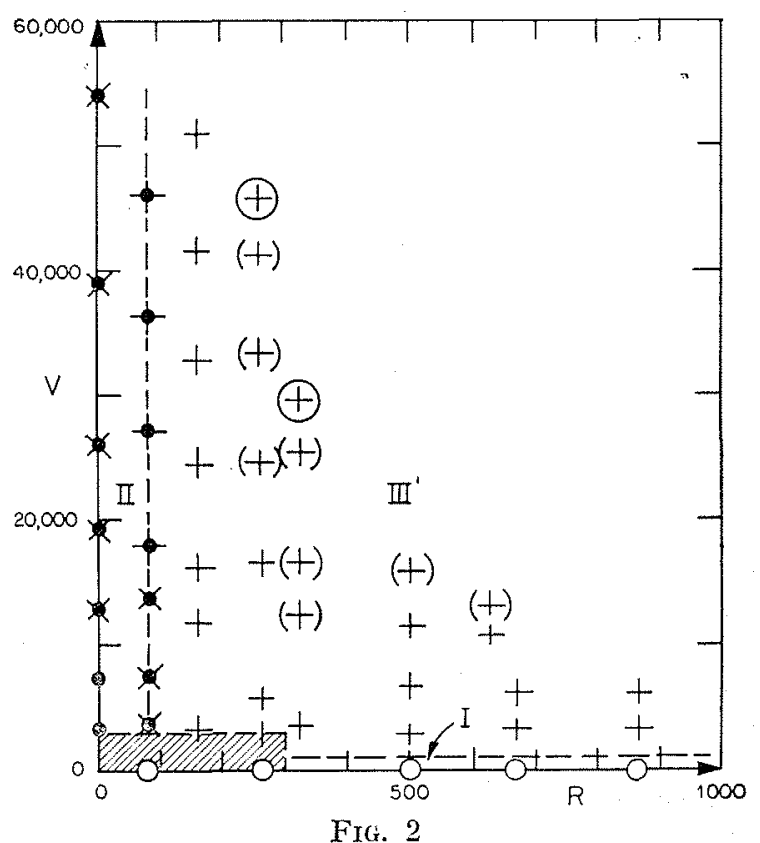

Schéma de régime pour l'installation $C_{\text {; }}$ discues à diaphragme central.

Regime diagram for arrangement $C$; disks with central hole.

$0.028 \mathrm{in}$. in outside diameter. Whenever possible it was quickly withdrawn; and sometimes, to ensure symmetry, a dummy tube was inserted through the corresponding tapping on the other side of the drum.

With the disks replaced by the nozzles (Figure 3), what may be termed regime $V$ was formed, in which there was downstream flow near the axis, near the wall and intermediately, with currents moving upstream in the two intervening zones. The same effect was obtained with the disks when they were put closer together so that the swirl in their neighbourhood was stronger. Most of a thread of colour injected at the periphery of the disk split at a small radius, part going through the hole and part moving upstream. This reverse current was driven back by and incorporated in the central stream which 


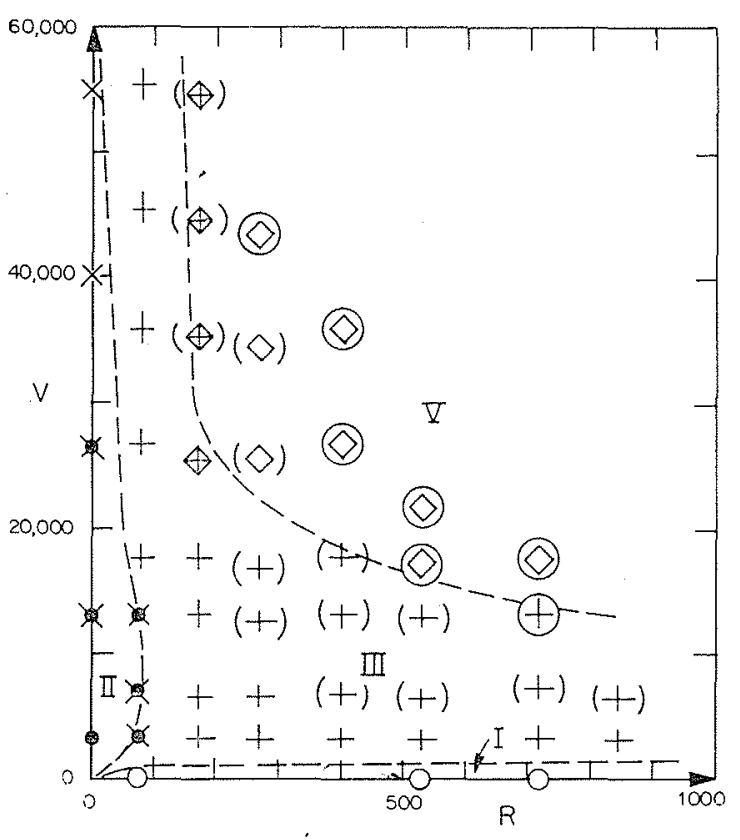

FIG. 3

Schéma de régime pour l'installation C; buses.

Regime diagram for arrangement $C$; nozzles.

continuait à se diriger vers le diaphragme, et l'autre, ayant presque atteint le disque selon un rayon plus grand, allait en général se mélanger au second courant de retour plus près de la paroi. Trois courants circulaient done dans la zone entre les deux composantes du débit à travers le diaphragme. Nous avons obtenu une répartition analogue avec les buses.

d) Installation D. - Ecoulement asymétrique : TUBE DE GAUCHE OBTURÉ PRÈS DU TAMBOUR.

Nous avons placé un bouchon plein légèrement à gauche de $\mathrm{L}_{1}$, permettant ainsi une injection de couleur à ce point. Ensuite, nous avons monté un des disques à diaphragme au point $z / a=8$, dans le tube de droite. Le régime II a pu se produire aux petites valeurs de $\mathrm{R}$, parce que la tendance à ce qu'un écoulement vers l'intérieur se produise sur la surface du disque l'emportait sur une tendance analogue au bouchon. Le schéma de régime (fig, 4) était presque identicue à ceilu de la figure 2, sauf qu'il a été possible de faire des observations sur une gamme plus étendue, et que nous avons pu constater une petite zone dans laquelle ce faible régime III se produisait. A l'apparition du régime III', l'écoulement vers l'aval, près de l'axe, était beaucoup plus important qu'avec l'installation $\mathrm{C}$, ce phénomène étant analogue à celui constaté dans les essais avec des buses verticales (Binnie et al., 1957), au divided into two portions; the inner continued on its way to the hole, and the outer, after almost reaching the disk at a larger radius, in the main found its way into the other reverse flow nearer the wall. There were thus three streams circulating in the region between the two components of the discharge through the hole. A similar pattern formed in the nozzles.

(iv) ArRangement D.--UNSYmmetrical Flow WITH THE LEFT-HAND TUBE BLOCKED NEAR THE DRUM.

A solid bung was inserted slightly to the left of $\mathrm{L}_{1}$, thus allowing colour injection there. First, one of the disks with a central hole was put in the position $z / a=8$ in the right-hand tube, Regime II was possible at low values of $\mathrm{R}$ because the tendency for inward flow to form over the disk prevailed over the similar tendency at the bung. The regime diagram (Figure 4) was almost identical with Figure 2, except that a larger range of observations was possible and that a small zone of the feeble regime III was noticed. When regime III' set in, the downstream flow near the axis was much stronger than with arrangement $\mathrm{C}$, the effect being similar to that seen in the vertical nozzle tests (Binnie et al., 1957) when a comparison was made between the flows with the back of the reservoir just uncovered and just covered. At the lower speeds, where injection outside the drum pro-

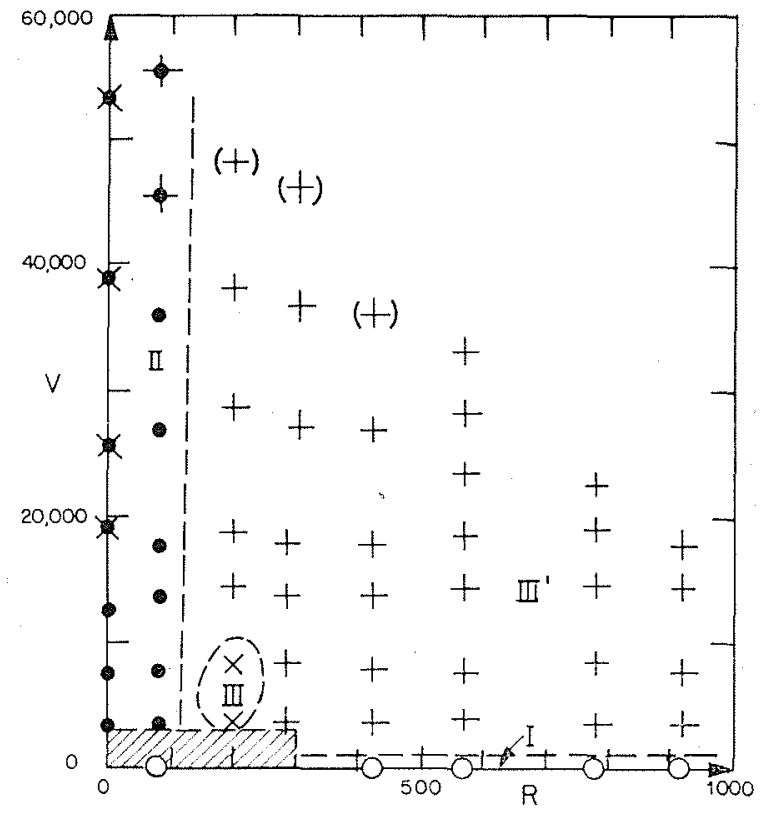

Fig. 4

Schéma de régime pour l'installation $D$; disque à diaphragme central.

Regime diagram for arrangement $D$; disk with central hole. 
cours desquels une comparaison a été faite entre les écoulements obtenus d'une part avec larrière du bassin juste découvert, et d'autre part, avec la même partie juste couverte. Aux vitesses plus faibles, où des injections à l'intévieur du tambour ont produit des résultats visibles, on voyait que le courant entrant par les Irous du côté gauche passait près de la paroi, jarvenant ensuite à la face du bouchon, de là a l'axe, et finalement par le diaphragme en passant par le tambour. Les injections de couleur on $R_{1}$ ont fait ressortir un courant de retour dans la zone située entre le tambour et le bouchon solide, revenant ensuite en passant plus près de la périphérie et de l'axe qu'auparavant. Ainsi, le régime IV se produisait assez près du bouchon solide, produisant près de la paroi et à environ mi-rayon des courants s'éloignant du lumbour et renfermant deux autres courants sécoulant en sens inverse.

Suivant une idée du profes̀seur H.B. Squire, nous avons remplacé le disque à diaphragme central par un disque poreux comportant 67 lrous de $1 / 32^{\circ}$ de pouce de diamètre, uniformément répartis et présentant une section totale presque identique à celle du diaphragme unique. L'objet, de cette modification était de déterwiner à quel point le régime ${\Pi I^{\prime}}^{\prime}$ constaté auparavant avait été stimulé par la concentration de débit en un point d'une surface solide sur laquelle existait un écoulement considérable vers lintérieur. Le schéma obtenu est reproduit sur 14 figure 5 .

On voit que le régime III' occupait une parlie réduite du schéma et que son courant cenIral était peu défini et relativement faible, dégénérant et se transformant en faible régime III a mesure que la vitesse augmentait. Toutefois, on a pu (comme d'habitude) aussi bien constaler un écoulement en sens inverse très net dans le régime III que dans le régime III'.

Nous avons ensuite remis le disque à diaphragme central dans le tube de droite et déplacé le disque poreux, l'installant à $\mathrm{L}_{1}$ au lieu du bouchon plein. La couche limite sur l'arrière de cette espèce de chambre tourbillonnante en cul-de-sac disparaissait, ou était tout au plus insignifiante; d'autre part, le courant axial vers le trou se trouvait affaibli.

En mettant le bouchon plein en $\mathrm{L}_{1}$ et en placant une des buses du tube de droite en $z / a=8$, hous avons obtenu les résultats de la figure 6 . Le régime $V$ n'apparaissail que sous une forme instable, tandis qu'il se produisait facilement lorsqu'on employait l'installation C (fig. 3). La comparaison des résultats symétriques (fig. 2 et 8) avec les résultats asymétriques correspondants (fig. 4 et 6) fait ressortir que ces deux derniers s'étendent sur un plus grand domaine que les duced visible results, the stream entering through the left-hand holes was seen to pass near the wall to the face of the solid bung, then to the axis and finally through the drum to the hole. Colour injected at $R_{1}$ indicated reverse flow into the region between the drum and the solid bung, whence it returned at both larger and smaller radii. Thus, not far from the solid bung regime IV occurred, with streams near the wall and at about half radius moving away from the drum and, inside them, two streams moving towards it.

At the suggestion of Professor H.B. Squire the disk with the central hole was replaced by a porous disk containing 67 holes of diametex $1 / 32$ in., uniformly distributed and having a total area almost the same as that of the single

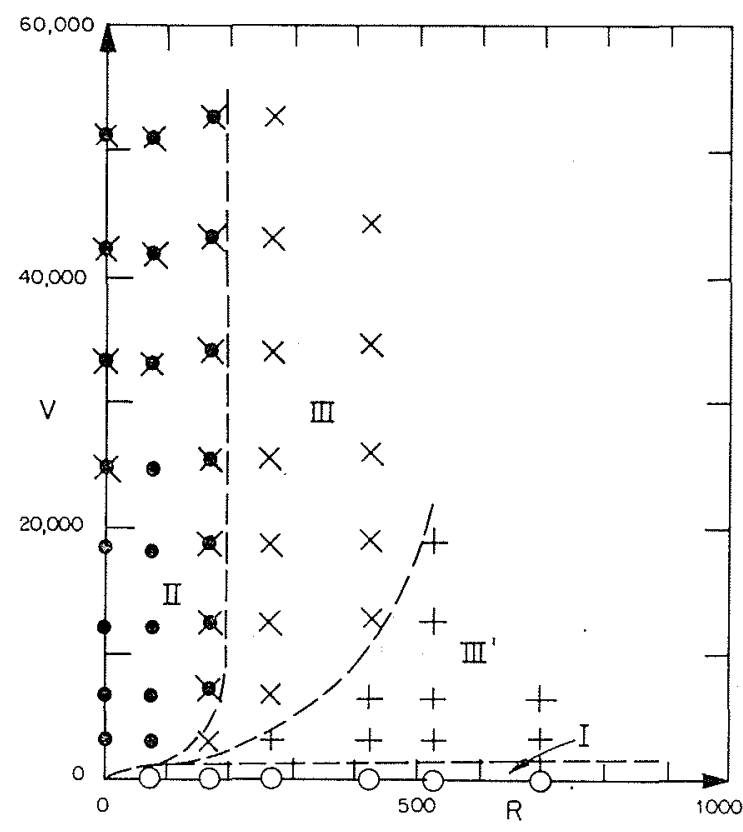

FIG. 5

Schéma de régime pour l'installation $\mathrm{D}$; disque poreux.

Regime diagram for arrangement $D$; porous disk.

hole. The purpose of the change was to discover how far the regime III' previously seen had been stimulated by the concentration of discharge at one point in a solid surface over which strong inward flow existed. The resulting diagram is shown in Figure 5. Regime III' now occupied a smaller part of the diagram, and its central stream was ill defined and comparatively weak; it decayed into the weak regime III as the speed was increased. Nevertheless, reverse flow was (as usual) clearly seen with regime III as well as with III'.

The disk with the central hole was then put 


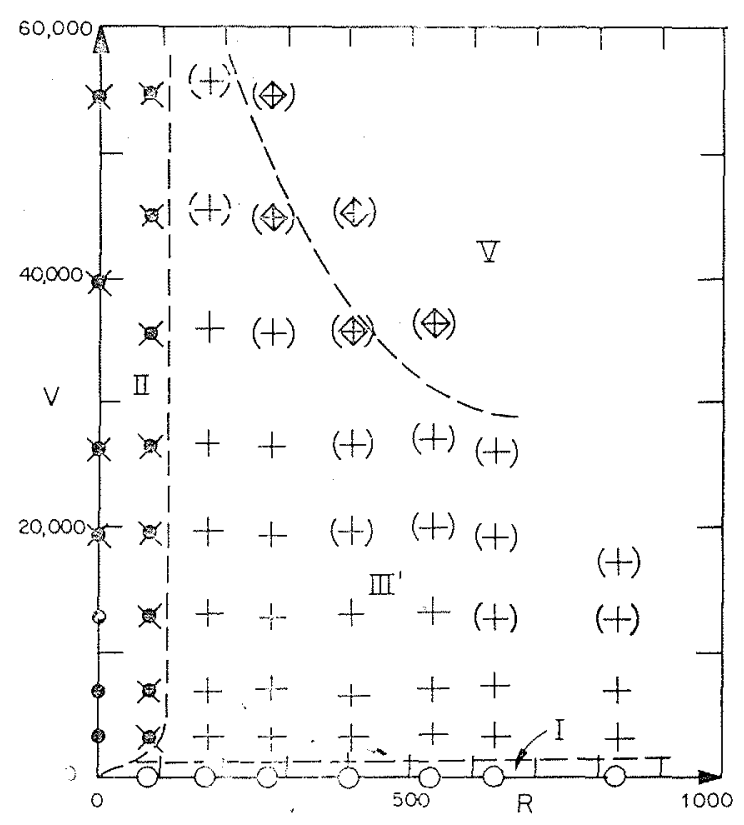

FIG. 6

Schéma de régime pour l'installation D; buse.

Regime diagram for arrangement $D$; nozzle.

premiers, et nous avons pu constater, en mesurant des niveaux dans les compartiments centraux el terminaux, que, pour les mèmes valeurs de $\mathrm{V}$ et $\mathrm{R}$, il allait une charge plus élevée avee l'installation C qu'avec l'installation $D$. On peut attribuer une partie de cette différence à la perte de charge supplémentaire aux trous du tambour, étant donné que la vitesse moyenne à travers ceux-ci est passée du simple au double, mais des expériences nous ont montré que cette perte n'était de toute façon que de l'ordre de quelques dixièmes de pouce. La différence principale était due aux tourbillons effectifs plus prononcés dans l'installation $C$, qui gênaient le débit à travers les orifices; cette augmentation de l'intensité du tourbillon est évidemment due à l'absence du bouchon plein et à la paroi avoisinante. Binnie et d'autres (1957) ont pu observer un phénomène analogue, dans lequel le débit tourbillonnant à travers une buse verticale diminuait considérablement si l'on réduisait légèrement la charge d'alimentation de telle façon qu'il y ait juste une surface libre dans le bassin.

On arrive à des considérations analogues si l'on compare les essais à disques (fig. 2 et 4 ) avec ceux à buses (fig. 3 et 6 ). Les orifices de ces deux types d'obstruction étaient dans les mêmes positions, de sorte que l'aire de la limite fixe entre l'orifice et le tambour était plus petite pour la buse que pour le disque. A valeurs égales de $\mathrm{V}$ et de $\mathrm{R}$, la buse était assujettie à un tourbillon back in the right-hand tube, and the porous disk was moved to $\mathrm{L}_{1}$ in place of the solid bung, Little or no botndary layer formed on the back of this kind of single-ended swirl chamber, and the axial stream towards the hole was weakened.

With the solid bung at $\mathrm{L}_{1}$ and one of the nozzles in the right-hand tube at $z / a=8$ the results plotted in Figure 6 were obtained. Regime $V$ was seen only in unstable form, whereas with arrangement $C$ (Figure 3 ) this type was readily induced. When the symmetrical results (Figures 2 and 3 ) are compared with the corresponding unsymmetrical results (Figures 4 and 6 ), it is noticeable that the latter pair cover a greater range than the former, and measurements of the levels in the central and end compartments showed that at the same values of $\mathrm{V}$ and $R$ a larger head was required with arrangement C than with D. A part of this difference call be attributed to the extra loss of head at the holes in the drum due to the doubling of the mean velocity through them, but experiments indicated that this loss was in any event only a few tenths of an inch. The main difference was due to the greater effective swirl inside arrangement $C$ which impeded the discharge through the orifices, and the reason for this greater swirl is clearly the absence of the solid bung and the adjacent wall. A like effect was noted by Binnie et al. (1957), who found that the swirling discharge through a vertical nozzle was considerably diminished if the supply head was slightly reduced so that a free surface just existed in the reservoir.

Similar considerations apply when comparison is made between the disk tests (Figures 2 and 4 ) and the nozzle tests (Figures 3 and 6). These two kinds of obstruction had their orifices

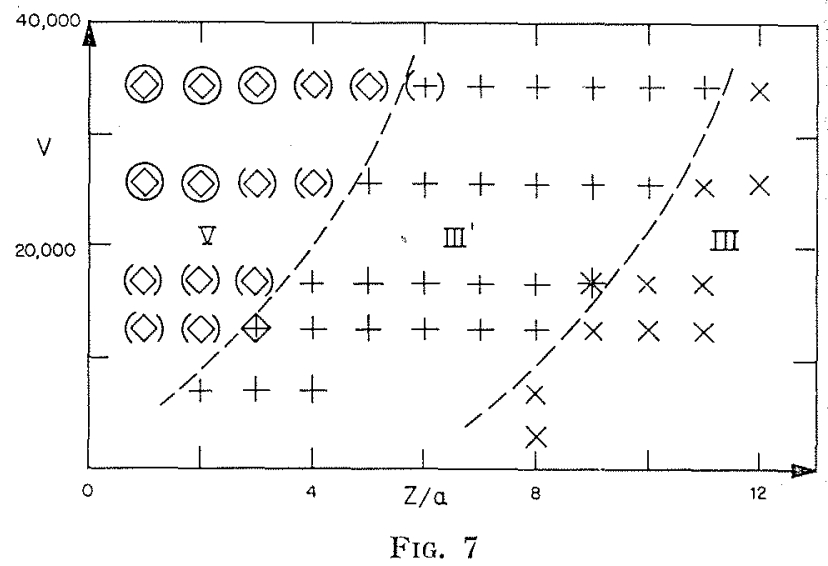

Schéma de régime pour l'installation $\mathrm{D}$; disque à diaphragme central installé $\dot{a}$ des distances diverses et avec $\mathbf{R}$ constant $=210$.

Regime diagram for arrangement $D$; disk with central hole at various distances and at constant $\mathbf{R}=\mathbf{2 1 0}$. 
effectif plus important, de sorte que le régime V ponvait s'y établir.

Pour mettre en évidence à quel point les régimes dépendaient de la position de l'obstruction, nous avons porté sur la figure 7 les résultats obtenus pour $\mathbf{R}=210=$ constante et en faisant varier la position du disque à diaphragme central, le bouchon plein étant en $\mathrm{L}_{1}$. Aux faibles valeurs de $z / a$, le régime $V$ se produisait facilement, mais à mesure que l'on augmentait ce rapport, on pouvait constater l'apparition des régimes moins complexes III' et III; lorsque le lourbillon était d'ordre supérieur, ces mutations se trouvaient considérablement retardées. Il est ćvident qu'une paroi fixe très longue était très efficace pour diminuer le tourbillonnement du courani principal passant près d'elle, et, aux grandes valeurs de $z / a$, le tourbillon sur la surface plane au voisinage du diaphragme devenait faible. in the same positions, hence the area of fixed boundary between the orifice and the drum was less with the nozzle than with the disk. At equal values of $V$ and $R$ the nozzle received a greater effective swirl, hence regime $V$ was possible in it.

To illustrate how greatly the regimes depended upon the position of the obstruction, Figure 7 gives the results when $\mathrm{R}$ was lept constant at 210 and the position of the disk with a central hole was varied, the solid bung being at $\mathrm{L}_{1}$. When $z / a$ was small, regime $V$ was easily produced but as this ratio was increased, the less complex types III' and III set in; at the higher swirls, the alterations were considerably delayed. Evidently a long length of fixed wall had a great effect in diminishing the swirl in the main stream close to it, and at large values of $z / a$ the swirl over the flat surface near the hole became feeble.

\section{IV. - RESULTATS EXPERIMENTAUX. LA FORMATION DES NOYAUX D'AIR IV-EXPERIMENTAL RESULTS.-THE FORMATION OF AIR-CORES}

Nous avons répété les essais que nous venons te décrire sur les installations C et D, mais cetie fois en laissant les orifices des obstructions découverts. Comme dans le cas des buses expérimentées par Binnie et d'autres (1957), la divervence du jet émergeant constituait le premier signe de tourbillonnement à l'orifice. Ensuite, les que les conditions étaient favorables, un * noyau » d'air s'établissait dans l'orifice; nous avons indiqué cette phase dans les figures 2, $3,4,6$ et 7 en mettant nos observations correspondantes entre parenthèses. Finalement, un noyau » s'établissait sur toute la longueur du lumbour, ayant un diamètre sensiblement unilorme, sauf près de la sortie; nous avons indiqué cette phase par des grands cercles complets. Ce « noyau était permanent et rectiliune en général, d'une forme ressemblant à celle observée dans les buses sous pression plutòt qu'au type ayant son origine en surface libre et diant considérablement perturbé par des ondes (Binnie et d'autres, 1957). Pendant l'évolution de la phase finale dans l'installation $\mathrm{C}$, on voyait que les « noyaux 》 avançaient simultanément en partant des orifices et se rencontraient à l'inlórieur du tambour. Ceci était une mise à Tepreuve sévère de la symétrie de l'écoulement, que la moindre erreur d'emplacement des buses pouvait détruire. En augmentant V davantage, on faisait augmenter le diamètre du « noyau».
The above experiments on arangements $C$ and $D$ were repeated with the orifices of the obstructions uncovered. As with the nozzles tested by Binnie et al. (1957), the first indication of swirl at the orifice was divergence in the issuing jet. Then, under favourable conditions, an air-core was established in the orifice, this stage being indicated in Figures 2, 3, 4, 6 and 7 by brackets round the regime observations. Finally, as indicated by large complete circles, a continuous core was rormed through the drum, apparently uniform in diameter except close to the exit. The core was steady and usually straight, resembling the form that had been seen in the pressure nozzles rather than the type which, originating at a free surface, is much disturbed by waves (Binnie et al., 1957). In the development of the final stage in arrangement $\mathrm{C}$, the cores advanced simultaneously from the orifices and met inside the drum. This was a severe test of the symmetry of the flow, which was upset if a small mistake had been made in positioning the nozzles. A further increase in $V$ increased the core diameter. With arrangement $D$ the core extended with its diameter unchanged up to the face of the solid bung without quite making contact with it. The formation of the core was reversible when the test was, as usual, carried out at constant $\mathbf{R}$ with $\mathbf{V}$ increased and then decreased, But, if $\mathbf{R}$ 
Dans l'installation D le « noyau » s'étendait, sans changement de diamètre, jusqu'à la face $\mathrm{du}$ bouchon plein, sans cependant le toucher. Lorsqu'on suivait la procédure normale, e'està-dire le maintien de $\mathbf{R}$ constant, tout en faisant d'abord augmenter $\mathrm{V}$ et le diminuant ensuite, la formation du « noyau » était réversible, Par contre, lorsqu'on faisait diminuer $\mathbf{R}$ avec $V$ constant, la pression à l'intérieur du tube diminuait et le "noyau se décomposait en bulles cylindriques aux extrémités arrondies, indiquant ainsi que les forces de tension de surface étaient devenues relativement importantes. Lors d'une phase ultérieure, où le débit était très lent et le tourbillonnement près de l'orifice était très diminué, ces bulles devenaient presque sphériques et se trouvaient entraînées au dehors.

L'observation des figures montre que les conditions favorables à l'apparition d'un « noyau » complet étaient sensiblement les mèmes que celles provoquant le régimè V. Le «noyau» le plus évolué a été obtenu en fixant $z / a$ à 8 et avec les buses disposées selon l'installation C (fig. 3); les deux points illustrés correspondant aux essais avec les disques (fig. 2) ont trait à un «noyau » plutôt instable. Dans l'installation $\mathrm{D}$, le «noyau» dans lorifice ne paryenait pas a avancer contre l'intense courant axial (fig. 4 et 6 ) et on ne pouvait produire le profil complet qu'en faisant diminuer $z / a$ (fig. 7), ou en remplaçant le bouchon plein par le bouchon poreux comme nous l'avons dit au paragraphe III. was decreased at constant $\mathrm{V}$, the pressure inside the tube diminished, and the core broke up into cylindrical bubbles with rounded ends, indicating that surface-tension forces had become relatively important. At a later stage, when the discharge was very slow and the swirl near the orifice was much reduced, the bubbles became nearly spherical and were swept out.

An examination of the figures reveals that the conditions favourable for the appearance of a complete core were much the same as those that promoted regime $V$. With $z / \alpha$ fixed at 8 , it was with the nozzles in arrangement $\mathrm{C}$ (Figure 3) that the core was best developed, with the disks (Figure 2) the two points shown refer to a somewhat unstable core. In arrangement $D$ the core in the orifice was unable to advance against the strong axial stream (Figures 4 and 6); and the complete form could only be produced by decreasing $z / a$ (Figure 7 ) or by replacing the solid with the porous bung as mentioned in $\$$ III.

\section{REFERFNCES}

Binne (A. M.) 1957, Quart. T. Mech. Appt. Math. 10, 276. Binvir: (A. M) et Harins (D. P.), 1950, Ouart. J. Mech. Appl. Math. 3, 89.

Binvie (A. M.), Hoonings (G. A.) et Kamex (M. Y. M.), 1957 . J. Fl. Mech. 3, 261.

linnie (A. M.) et Teare (J. D.), 1956, Proc. Roy. Soc. A 235,78 .

Reynoxus (0.), 1886, Phil. Mag. (5) 21, 185. Also Scientific Papers, 2, 311

Тацвот (L.), 1954, J. Appl. Mech., 21, 1.

Thomson (J.), 1857, Brit. Assoc. Report (Dublin), Transactions of Sections, p. 39. Also Papers in Physics and Engineering, p. 147.

VaISEY (M. G.), 1956, Proce 9th Intern. Congr. Appl. Mech., Brussels, section 1 .

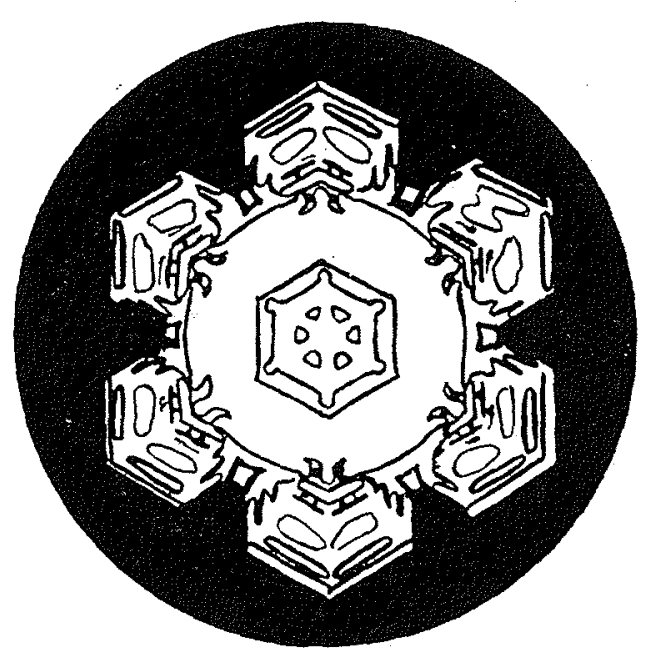

